\title{
Two New Marine Sponges of the Genus Halichondria (Halichondrida: Halichondriidae) from Uljin, Korea
}

\author{
Dong Won Kang ${ }^{1, *}$, Chung Ja Sim² \\ ${ }^{1}$ Natural History Division, Ministry of Education, Science and Technology National Science Museum, \\ Daejeon 305-705, Korea \\ ${ }^{2}$ Department of Biological Sciences, College of Life Science and Nano Technology, Hannam University, \\ Daejeon 305-811, Korea
}

\begin{abstract}
Two new marine sponges, Halichondria jangseungenesis n. sp. and H. nagokenesis n. sp., of the family Halichondriidae, were collected from Uljin-gun, Gyeongsangbuk-do, Korea by SCUBA diving during the period from Apr 2007 to Aug 2007. Based on their spicule composition and skeletal structure, H. jangseungenesis n. sp. appears to have a close similarity with H. panicea (Pallas, 1766); however, they differ in length of spicule. The spicule length of oxea of $H$. jangseungenesis $\mathrm{n}$. sp. is shorter than that of $H$. panicea. Based on their spicule composition and growth form, H. nagokenesis n. sp. is quite similar to H. cylindrata Tanita and Hoshino, 1989; however, but they differ in length of spicule. The spicule length of oxea of $H$. nagokenesis $\mathrm{n}$. sp. is longer than that of $H$. cylindrata.
\end{abstract}

Keywords: Halichondria, new species, sponge, Korea

\section{INTRODUCTION}

Marine sponges of the family Halichondriidae Gray, 1867 have an irregular choanosomal skeleton consisting of a high density of spicules arranged in confusing, vague, ill-defined, directionless tracts and spicules (Hooper et al., 1997). Finding conspicuous anatomical characteristics of the genus Halichondria has been a particular challenge for sponge taxonomists (Carvalho and Hajdu, 2001).

The genus Halichondria is characterized by a tangential ectosomal skeleton carried by subectosomal spicule tracts or brushes separated by subdermal spaces. Megascleres of the genus Halichondria have only oxeas or derivates in a wide range of sizes (de Laubenfels, 1936; Hooper and van Soest, 2002). Approximately 110 species from all regions and habitats have been recorded (Hooper and van Soest, 2002). Nine species of Halichondria from Korean waters have been reported (Kim et al., 1968; Rho and Lee, 1976; Kang and Sim, 2008a, 2008b; Jeon and Sim, 2009; Kim and Sim, 2009).

\section{MATERIALS AND METHODS}

Sponges were collected from Uljin-gun, Gyeongsangbuk-do,

(C) This is an Open Access article distributed under the terms of the Creative Commons Attribution Non-Commercial License (http://creativecommons.org/ licenses/by-nc/3.0/) which permits unrestricted non-commercial use, distribution, and reproduction in any medium, provided the original work is properly cited.
Korea by SCUBA diving during 2007. Specimens were fixed in $95 \%$ or $99.9 \%$ ethanol. Spicules were observed under a light microscope (Carl Zeiss Axioskop II; Carl Zeiss, Jena, Germany). Identification was made on the basis of external features of sponges, growth form, skeletal structure, and spicule size and form. For observation of the endosomal skeletal structure, thin free-hand sections were made with specimens hardened in alcohol using a surgical blade. Spicules were prepared by dissolving a piece of sponge in sodium hypochlorite and examined under an scanning electron microscopy (Rützler, 1978; Hooper, 1996). Holotypes of two new species have been deposited in the Department of Biological Sciences, Hannam University, Daejeon, Korea.

\section{SYSTEMATIC ACCOUNTS}

Phylum Porifera Grant, 1836

Class Demospongiae Sollas, 1885

Order Halichondrida Gray, 1867

Family Halichondriidae Gray, 1867

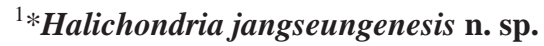
Kang and Sim, 2011 (Fig. 1)

\footnotetext{
*To whom correspondence should be addressed

Tel: 82-42-863-8573, Fax: 82-42-863-8576

E-mail: soma234@hanmail.net
}

Korean name: ${ }^{1}$ *장승해변해면 (신칭) 

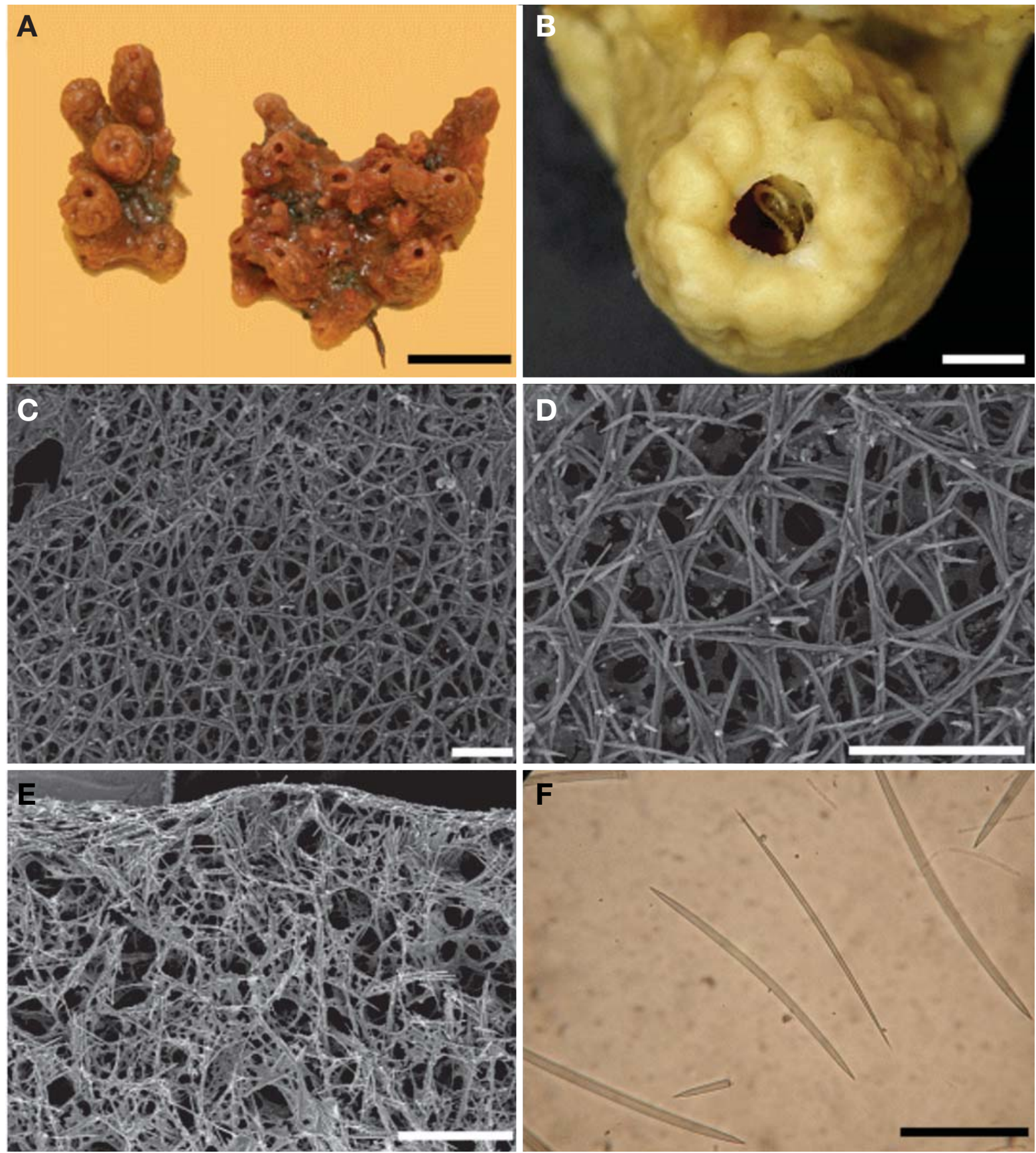

Fig. 1. Halichondira jangseungenesis n. sp. A, Entire animal; B, Oscule opened at the top of the column, like a chimney; C, D, Surficial skeletal structure; $E$, Endosomal skeletal structure (longitudinal section); $F$, Oxeas. Scale bars: $A=2 \mathrm{~cm}, B=0.2 \mathrm{~cm}, C$, $\mathrm{D}=200 \mu \mathrm{m}, \mathrm{E}=400 \mu \mathrm{m}, \mathrm{F}=100 \mu \mathrm{m}$.

Material examined. Holotype (Por. 104), Uljin-gun, Gyeongsangbuk-do, 1 Apr 2007, SCUBA $25 \mathrm{~m}$ depth, by Lee JR, deposited in the Department of Biological Sciences, Hannam University, Daejeon, Korea.

Description. Encrusting with chimney. Sized up to $4 \times 3$ $\mathrm{cm}$ wide and $0.2 \mathrm{~cm}$ thick. Oscules, $0.2-0.5 \mathrm{~cm}$ in diameter, opened at top of chimney. Osuclar chimney, characteristically grooved. Colour orange in life and gradually changed to ivory in alcohol. Texture Firm and compressible. Surface smooth. Ectosomal skeleton tangential arrangement and intercrossing bundles of spicule. Choanosomal skeleton composed of many spicular tracts and individual spicules scatter- 

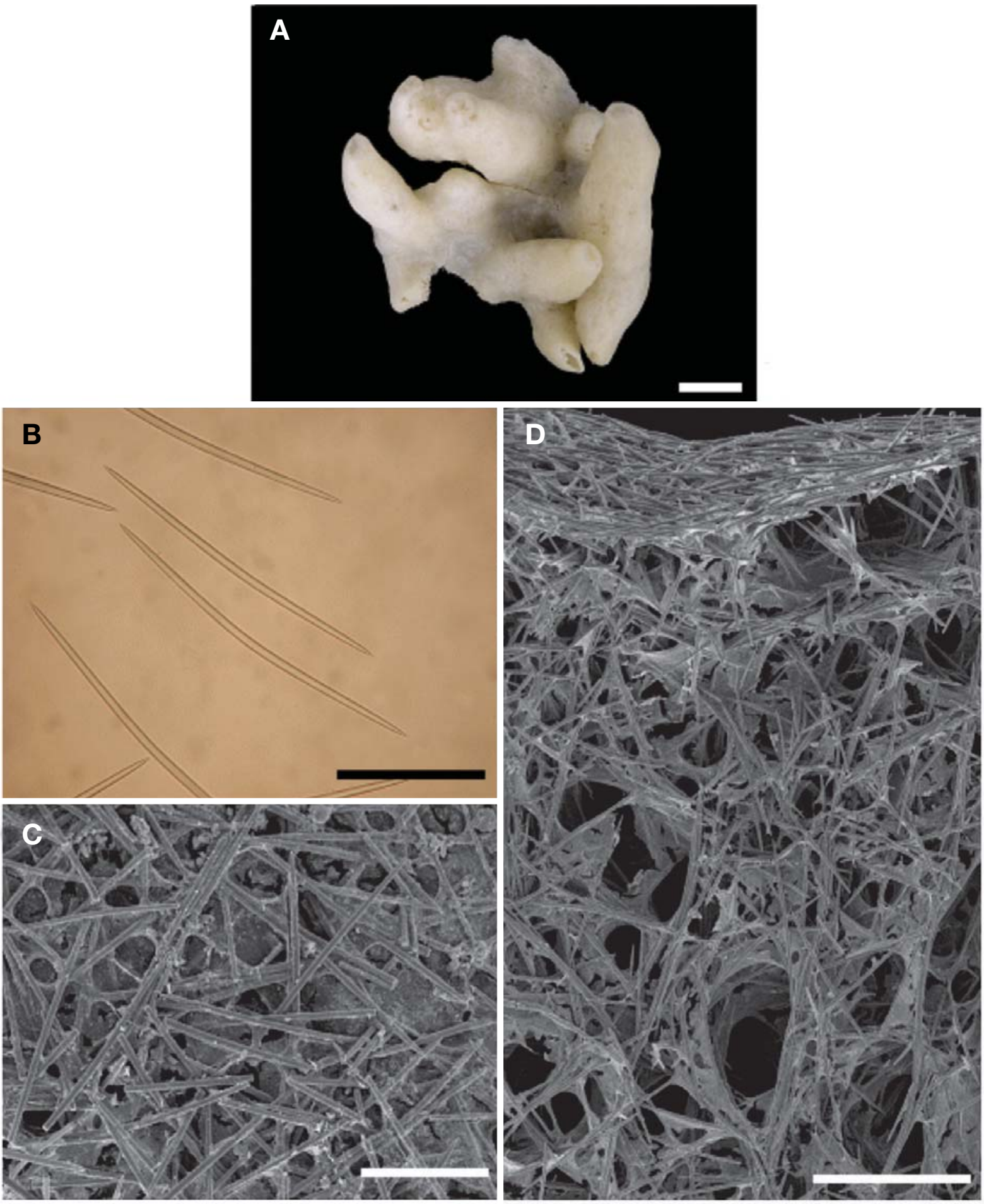

Fig. 2. Halichondria nagokenesis n. sp. A, Entire animal; B, Spicules (oxeas); C, Surficial skeletal structure; D, Skeletal structure (longitudinal section). Scale bars: $A=1 \mathrm{~cm} ; B, C=300 \mu \mathrm{m} ; D=500 \mu \mathrm{m}$.

ed whole body in confusion. Spicules composed of one type of oxea without microscleres. Oxea approximately $215-290$ $\times 5-7.5 \mu \mathrm{m}$ in size.
Etymology. The species is named after the type locality, Janseungbaegi, Uljin-gun, Korea.

Remarks. Halichondria jangseungenesis $\mathrm{n}$. sp. is similar to 
H. panicea (Pallas, 1766) in type of spicule and choansomal skeletal structure; however the former differs from the latter in size of spicule. The oxea of spicules is smaller than that of $H$. panicea. The shape of H. surrubicunda Hoshino, 1981, and $H$. corrugate, Diaz et al., 1993, were described as an irregular encrusting form with or without exhallent hollow cylinder/massive-lobate with oscular chimneys, and the composition of spicules with one type of oxea; thus, $H$. jangseungenesis $\mathrm{n}$. $\mathrm{sp}$. is close to these two species in these aspects. Nevertheless, they differ from this new species in their size of oxea, 300-500 $\mu \mathrm{m}$, while in this new species $250 \mu \mathrm{m}$.

\section{${ }^{1}$ Halichondria nagokenesis $\mathbf{n} . \mathbf{s p}$. Kang and Sim, 2011 (Fig. 2)}

Material examined. Holotype (Por. 105), Uljin-gun, Gyeongsangbuk-do, Korea, 1 Aug 2007, SCUBA 20 m depth, by Lee JR, deposited in the Department of Biological Sciences, Hannam University, Daejeon, Korea.

Description. Thick encrusting with numerous erect hollow cylindrical tube, $2.5-5 \mathrm{~cm}$ high. Sized up to $8 \times 5 \mathrm{~cm}$ wide and $1.5 \mathrm{~cm}$ thick. Oscules, $0.3-0.5 \mathrm{~cm}$ in diameter, opened at top of each tube. Color ivory in ethyl alcohol. Texture soft. Surface smooth. Ectosomal skeleton tangential arrangement. Choanosomal skeleton large and extensive subchoanosomal space present, irregular and large-meshed net of spicuels, columns with spicules extend to surface and supporting ectosomal skeleton. Spicules composed of one type of oxea without microscleres.

Oxea approximately $500-670 \times 10-15 \mu \mathrm{m}$ in size.

Etymology. The species is named after the type locality, Nagok, Uljin-gun, Korea.

Remarks. $H$. nagokenesis n. sp. resemble $H$. cylindrata Tanita and Hoshino, 1989, in their growth form, with a welldeveloped hollow cylinder. Also, oscules open at the top of each tube. However, oxea of the new species is larger than that of $H$. cylindrata. The length of oxeas in the new species, $500-670 \mu \mathrm{m}$, is nearly double that of the H. cylindrata, 230$315 \mu \mathrm{m}$. This new species is similar to H. osculum Lundbeck, 1902, in its growth form, spicule composition and skeletal structure. However, oxea of H. nagokenesis n. sp., 500-670 $\mu \mathrm{m}$ in length, is smaller than that of H. osculum 600-920 $\mu \mathrm{m}$ in length.

\section{ACKNOWLEDGEMENTS}

We thank members of IN THE SEA KOREA Co. Ltd, Dr. Sa
Heung Kim, Jong Rak Lee, Yong Tae Kim and Hack Chul Kim for collecting specimens used in the study. This research was funded by the Marine Biotechnology Programme of the Ministry of Land, Transport and Maritime Affairs (MLTM) of the Korean Government and a grant funded by the Korea Science and Engineering Foundation (KOSEF) (NO. 20100002076).

\section{REFERENCES}

Carvalho MS, Hajdu E, 2001. Comments on brazilian Halichondria Fleming (Halichondriidae, Halichondrida, Demospongiae), with the description of four new species from the São Sebastião Channel and its environs (Tropical Southwestern Atlantic). Revista Brasileira de Zoologia, 18(Suppl 1):161180.

de Laubenfels MW, 1936. A discussion of the sponge fauna of the Dry Tortugas in particular and the West Indies in general, with material for a revision of the families and orders of the Porifera. Papers from the Tortugas Laboratory, 30:1225.

Diaz MC, Pomponi SA, Van Soest RWM, 1993. A systematic revision of the central West Atlantic Halichondrida (Demospongiae, Porifera). Part. III: Description of valid species. Scientia Marina, 57:283-306.

Hooper JNA, 1996. Revision of the Microcionidae (Porifera: Poecilosclerida: Demospongiae) with description of Australian species. Memoirs of the Queensland Museum, 40:1-626.

Hooper JNA, Cook SD, Hoobbs LJ, Kennedy JA, 1997. Australian Halichondriidae (Porifera: Demospongiae) I. Species from and the Beagle Gulf. In: Proceedings of the Sixth International Marine Biological Workshop (Eds., Hanley JR, Caswell G, Megirian D, Larson HK), Northern Territory, pp. 1-65.

Hooper JNA, van Soest RWM, 2002. Systema Porifera. A guide to the classification of sponges. Kluwer Academic/Plenum Publishers Press, New York, pp. 1-1101.

Jeon YJ, Sim CJ, 2009. A new record of genus Halichondria (Demospongiae: Halichondriada: Halichondriidae) from Korea. The Korean Journal of Systematic Zoology, 25:137139.

Kang DW, Sim CJ, 2008a. Two new sponges of the genus Halichondria (Halichondida: Halichondriidae) from Korea. Animal Cells and Systems, 12:65-68.

Kang DW, Sim CJ, 2008b. Two new marine sponges of the genus Halichondrida (Halichondida: Halichondriidae) from Korea. The Korean Journal of Systematic Zoology, 24:205208.

Kim HR, Sim CJ, 2009. A new species of the family Halichondriidae (Demospongiae: Halichondrida) from Jeju-do Island, Korea. The Korean Journal of Systematic Zoology, 25:179- 
181.

Kim HS, Rho BJ, Sim CJ, 1968. Marine sponges in south Korea (1). The Korean Journal of Systematic Zoology, 11:37-48.

Rho BJ, Lee KH, 1976. A survey of marine sponges of Haeundae and its adjacent water. Journal of Korean Research Institute for Better Living, Ewha Womans University. 17:93111.
Rützler K, 1978. Sponges in coral reefs. Coral reefs: research methods. Monographs on oceanographic methodology. Vol. 5 (Eds., Stoddart DR, Johannes RE). UNESCO, Paris, pp. 299-313.

Received October 17, 2010 Accepted March 3, 2011 